\title{
1989 年ボイラのオンラインメンテナンス開始
}

井上一信*

\section{1.はじめに}

当社は, 主にボイラ及び関連機器等の製造販売, メンテ ナンスを手掛けており, 経営理念「世界のお客様に対して, 省エネルギーと環境保全でお役に立つ」を実現するために， 工場のトータルソリューションをグローバルに提供し，ワ ンストップメンテナンスを展開している，それを支えてい るのが，ビフォアメンテナンスであり，その実現のため， 1989 年より通信回線を利用したオンラインメンテナンス を活用している。

今では, 2001 年に標準装備されたコマツの KOMTRAX (コムトラックス) や GE の航空機エンジンサービス等, 様々な業界で当たり前の IOT の仕組みになっているが, 当社が先駆けて取り組んだオンラインメンテナンスの開発 当時を振り返る。

\section{2. 快適なボイラシステムを目指して}

設計者の机上には A 2 サイズのドラフターつまり手描 きで図面を描く装置，フロアーには共用のワードプロセッ サ, 連絡手段は電話と FAX, 特別の資料でない限り手書 きと音声が伝達の手段だった。コンピュータと呼ばれるも のは, 個人で買ったプログラム電卓（ポケットコンピュー 夕）〈らい. PC-8800 シリーズの全盛期であったが，ソ フトウェアの品揃えから, ゲームをするための機械であっ て，自分でN 88-BASICを組んで使う人はあまりいない 時代だった。ただ，自動車の世界では，既に 1970 年代に 流行した「OKモニター」(運転者が座ったまま車の故障診 断できる予防安全装置) が影を潜め，コンピュー夕制御に よる快適な運転が実現されていた．確かこの当時のトヨタ のクラウンには, 大小 48 個の ICチップが搭載されてい たと記憶している.こんな状況の中で, 今の当社の主力で もある工場向けボイラ販売部門から, 開発企画が発案され た.コンピュータを活用することによるボイラ事業の将来 ビジョンの企画である.

コンピュータの利用によって, ボイラの制御の質が変革 でき, 蒸気ストップを極力無くし, 安全性を高め, 適正な 操作・メンテナンスをボイラが診断できる可能性があり, 通信回線を利用したメンテナンス体制により, 必ず，ユー ザーとメンテナンスの両方に利益をもたらすことができる.

Boiler Online Maintenance Started in 1989

* Inoue, Kazunobu

三浦工業(侏) 新事業開発・熱利用事業本部

松山市堀江町 7 番地（广799-2696）

inoue_kazunobu@miuraz.co.jp

2020.4.22 受理

https : //doi.org/10.4325/seikeikakou.32.325
コンピュータでは，タイマーやリレーを主とした単に入力 の閾值による制御ではなく，ソフトウェアによる論理判定 やデー夕を生きた情報として活用することができ，それを 出力制御にも活かしていける。 そして，その情報をメンテ ナンスにも活用すれば，知らないうちに快適な世界が広が る自動車の様な事ができる，つまり，オンラインのメンテ ナンスシステムは，単に通信で繋ぐだけではなく，本体そ のものから変える必要がある.

将来, コンピュータは廉価になる可能性が高く, ボイラ 制御にコンピュータが不可避であるならば，今からそれを 追求し，社員も含めてそれに慣れていく必要がある。すな わち, コンピュータ制御されたボイラを開発し, 納入して いかないと何も始まらない.

\section{3. チームカとスピード}

企画案を作った方が, 企画書と共に設計部長として異動 してこられた。そして，全社の初回会合が招集された。 ボ イラ設計, 営業推進, メンテ推進, 電機設計, システム設 計, 製造, 生産技術, 品質保証, 検査, 購買の各部門から 代表者が集合し，開発企画が説明され，業務分担とスケ ジュールが決定し, 商品開発における責任部署がボイラ設 計部に決定した. 1987 年 8 月のことである.この時点で, 社内の開発体制が明確になった.

私もこの会合に休暇の課長の代理として出席していた。 入社 4 年目の私は, 会議の中で少し熱くなってしまって発 言した手前, 課長の代わりにこの仕事をやらせて欲しいと 進言して商品機開発のリーダとなった。

1988 年 10 月の発売に向けて各部門が担う役割分担と協 力の下，商品化がスタートした. 既に机上の整理が終わっ ている企画案と先行して検討がされていたマイコンボード の仕様をベースに，入力センサーと出力制御を駆使した論 理の実機検証の繰り返し, お客様が必要なエネルギー管理 のための情報の絞込み, メンテナンスに必要な情報の精査 など, 拠点の営業・メンテナンスの代表の方とも月次で打 合せをし, 試験内容と製品仕様を協議した. 発売まで残り 14 ケ月という期間の中で, 制御を行うマイコンボードや ソフトウェアを並行して開発しているため, マイコンボー ドのハード設計, 続くソフトウェア設計の詳細に係る仕様 決定が遅れれば，発売スケジュールも遅れてしまう。初期 の段階から, ボイラ設計, 電機設計, 営業, メンテナンス の各部門の協力が無ければ，このスケジュールでの商品化 は出来なかっただろうと今でも思う。当時の当社は, まだ 平均年歯令 30 代前半で，この開発の実務メンバーも，30 歳前後の活力あふれる人で構成されていて, 当時の私には わからなかったが，互いに積極的に活動できる環境が会社 
や上司からも与えられていたのだろうと思う。みんなで同 じ目標に向かって，突進している感じだった。

商品に搭載する新たな機器やセンサーも含めて開発試作 品が完成したのが，1987 年の 12 月だった。 今では許され ないが，昼夜を徹する覚悟！と言うとおこがましいが，そ んな時代だった. 出来上がった試作機を早速実験場に設置 して, 電機設計の先輩と 24 時間動かしてみようと意気込 んで泊まり込んだが, 午前 0 時にアラームを発生してボイ ラは停止した. 24 時間分のエネルギー管理データやメン テナンスデータの更新処理が, 制御の妨げになってしまった.

この開発をやり始めて, あっという間に時が経って行っ た。やり甲斐にまっしぐらだった気がする，気が付けば大 䀲日だった。 1 月の元旦と 2 日は, みんなで久しぶりに ゆっくりと家で休養した.

\section{4. エピソード}

1988 年 3 月に商品試作機が完成した. ここからは, 商 品機としての本格的な評価が開始される. 12 月の試作機 での指摘事項に加えて, 商品試作機は品質・安全面での最 終評価, 実際のメンテナンス作業を実施しての評価, コス トの妥当性など，商品として社内評価を受けることになる． 特に, 新たに組み込まれたコンピュータ制御は, 机上の確 認試験に加えて, 実機での試験が多岐にわたり, 多くの時 間を費やして，みんなで取組んで検証した。

商品機には，ちょっとしたエピソードがある．このモデ ルで新しいイメージを作るために色にもこだわった。とこ ろが, 社内で塗装できる色の数には制限がある.そこで担 当者は, 他事業部商品の似た色を交渉して一つにまとめ, その分新たな色を追加した. インディゴブルーと名付けた 紺色は，今まで赤を基調とした当社の制御パネルとは全く 違った印象になった。 また，この商品試作機は，役員に見 てもらうことになったのだが，昼休みに屋外の明るい場所 で見せたところ，本体ケーシングのグレー色が明るすぎて 污れが目立つと指摘されてしまった. その時, デザインの 担当者は，あっけらかんと「夕方までに塗り直すので，も う一度見に来てください」と言った. 夕方, 室内で, 同じ ものを見せた。「これならいいだろう」あっさりと許可が 下りた。ボイラは, やっぱりボイラ室と同じ環境で評価す べきだなと思いつつも，こういったメンバーの知恵や信念 が開発を支えているのだと痛感した。

\section{5. 一気にオンラインメンテナンスへ}

商品試作機が出来上がり, 形となったころ, 周辺でもい ろいろな準備が始まった。

出荷の試運転は, パソコンを使って通信でデータ保存し
て検査記録を残し作業を合理化. メンテナンスの教育は, 3 日間のカリキュラムで計 5 組, 主任以上に研修を実施. テキストや机上で動作確認するシミュレータツールを作成. 研修に参加できない人のために，ビデオを作成して支店に 配布.メンテナンスでボイラのコンピュータからデータを 引き出すためのツールとして, ハンディターミナルを採用 した．今ならモバイル PC や iPad で通信ということにな るのだろうが，有線でのデー夕読み达みだった。営業ツー ル作成のために, 営業や開発にかかわっているメンバーと, 社外のコピーライターも招いてカタログや営業ツールを作 成. 販売活動として, 全国 12 会場でセミナー形式のキャ ンペーンを実施. 地元県内でのモニター販売を 2 台実施し, 発売までに検証＆改良した。

モニター販売を実施するために, 電話回線を使ってモニ ター機のデータ通信が出来るように準備を行った.この段 階では, グラフィカルなものではなく, 単なる数字とアル ファベットの通信データであったが，モニター機のところ に行かなくても, 設計部門のフロアーからいつでもリアル タイムにモニタリング，エネルギー管理データやメンテナ ンスデータを確認することが出来た。

これを見た役員から，これはメンテナンスで活用できる， すぐにシステム化を進めるべきだとの声が上がった。オン ラインメンテナンスの実行は, 次のステップとして既にボ イラ本体には装備されていたが, 出来るだけ早くシステム を作り上げることが会社の方針となり，商品販売に向けた 活動と並行して, メンテ推進部門主導でオンラインのシス テムを構築していくことになった. その結果, 1989 年 2 月にオンラインシステムが完成し, 本社のオンラインセン ターがスタートすると同時に, 各支店にも同様のシステム が配布され全社システムの運用が始まった。設計部門にも 同様にシステムが設置され, 販売先のボイラのデータを活 用した初期改良を進めて行った。

\section{6. 振返って}

世の中の情報をしっかり見つめて将来を見通しビジョン を描くことの重要性, ビジョンを出来るだけ多くの人が共 有して社内環境とメンバーの一体感が醸成されていること, いろんなことを想定して緻密にテーマやスケジュールが立 てられていくこと, 事業成功のために重要なことをこの仕 事で学ばせていただいた。

当社にとって, オンラインメンテナンスはお客様との WIN-WIN の関係のために無くてはならないものとなって いる．若い頃にこの仕事を経験できるチャンスをいただけ たことは, 私にとっても大きな財産になったと思うし, 仕 事次第で人の成長や企業の財産は変わっていくのだと思う. 